\title{
Scientists say 'no' to UK exit from Europe in Nature poll
}

\section{Most polled researchers in Britain and the wider EU think that the union benefits science.}

BY DANIEL CRESSEY

The charged question of whether the United Kingdom should stay in the European Union - to be put to a national referendum on 23 June - splits the general population almost evenly. But most scientists want the country to stay in, suggests a Nature poll of nearly 2,000 researchers living in the EU, both inside and outside the United Kingdom (see 'Scientists speak on a Brexit').

Most of the polled researchers also think that a British exit, or 'Brexit', would harm science in the nation and in the EU at large.

Political debate concerning a Brexit has revolved heavily around immigration, the economy and infighting in the country's ruling Conservative Party. Prime Minister David Cameron supports the 'in' camp, but several high-profile members of his party want out.

However, science is making inroads into the discussion. "Research and innovation are actually coming more into the debate," says Mike Galsworthy, co-founder of the advocacy group Scientists for EU. "It's going to get more heated around that issue." On $10 \mathrm{March}$, The Times newspaper published a letter extolling the benefits to science of EU membership, signed by more than 150 researchers at the University of Cambridge who are fellows of the Royal Society. "I think in the sciences, it's clearly overwhelmingly in favour of staying in," says lead signatory Alan Fersht, a Cambridge chemist.

Scientists in favour of staying note that UK universities receive around $16 \%$ of their total research funding directly from the EU, and that membership allows researchers to move freely between member states and to work with no restrictions (see Nature 530, 15, 2016).

But pro-Brexit Conservative justice minister Michael Gove has suggested that money that the United Kingdom currently gives to the EU as part of its membership could be invested in science if the country leaves. And cancer researcher Angus Dalgleish - who is campaigning for the United Kingdom to leave the union - complained about EU regulation of science on the television programme Newsnight on 10 March. The campaign to leave is making science a major point of its activities, says Jamie Martin, an advocate for the leave side and a former special adviser to Gove.

\section{SCIENTISTS SPEAK ON A BREXIT \\ Nature surveyed researchers in the United Kingdom and the wider European Union on the impact of a British exit from the EU.}

\section{UK RESEARCHERS}

Should the UK exit the EU or remain?

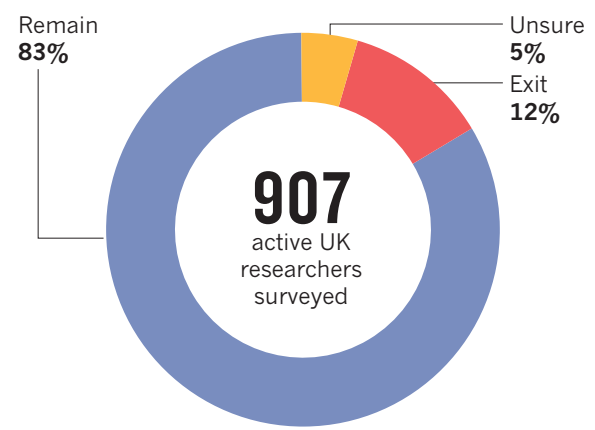

When only the 666 who plan to vote in the referendum are included, the figures shift slightly — to $80 \%$ remain and $14 \%$ exit.

E $\begin{aligned} & \text { BILLION (US\$19 BILLION) } \\ & \text { Approximate annual UK } \\ & \text { contribution to the EU budget }\end{aligned}$

E $4 \begin{aligned} & \text { BILLION } \\ & \text { Funding received by UK } \\ & \text { researchers from EU since }\end{aligned}$

"The UK is too small to sustain a world-class scientific programme in isolation." RESEARCHER WHO WILL VOTE TO REMAIN

"We could be more open to researchers coming from outside the EU who are currently discriminated against." RESEARCHER WHO WILL VOTE TO EXIT

\section{EU RESEARCHERS EXCLUDING UK}

Should the UK exit the EU or remain?

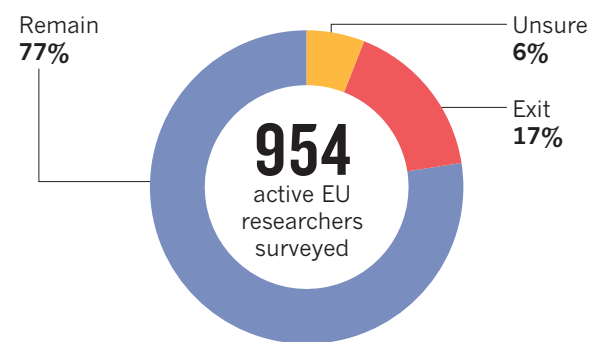

What impact would a UK exit from the EU have on UK science?

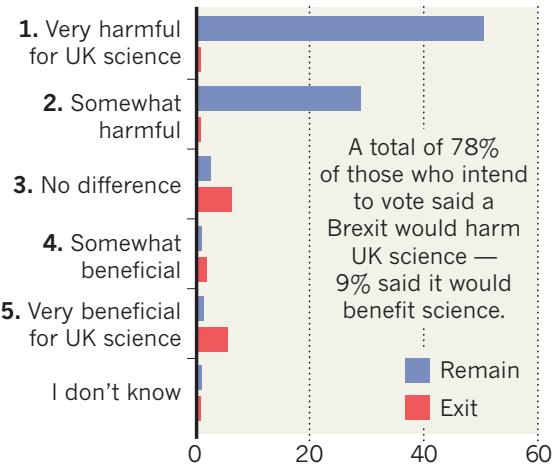

Proportion of 629 active UK researchers who know how they will vote (\%)

\section{UK POPULATION}

Should the UK exit the EU or remain in the $\mathrm{EU}$ ?

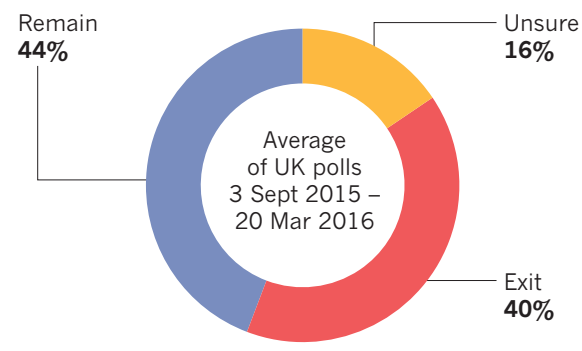

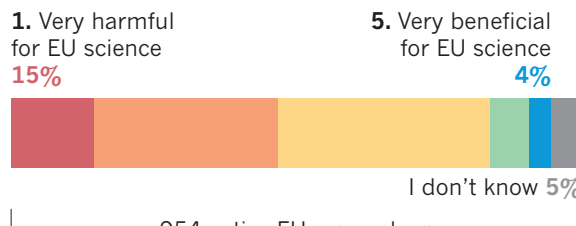

Most scientists think that, if the United Kingdom eft the EU, science in the nations left behind would suffer, albeit less than UK science. 


\section{CORRECTION}

In the News story "Scientists say "no" to UK exit from Europe in Nature poll' (Nature 531, 559; 2016), the labels numbered 2 and 4 in the graphic "What impact would a UK exit from the EU have on UK science?' were the wrong way round. The opening paragraph also potentially implied that the poll was more representative of scientists in the UK and greater EU than perhaps was warranted. 